\title{
Self-organized lateral inhibition improves odor classification in an olfaction-inspired network
}

\author{
Bahadir Kasap ${ }^{1 *}$, Michael Schmuker ${ }^{1,2}$ \\ From Twenty Second Annual Computational Neuroscience Meeting: CNS*2013 \\ Paris, France. 13-18 July 2013
}

The insect olfactory system is capable of classifying odorants by encoding and processing the neural representations of chemical stimuli. Odors are transformed into a neuronal representation by a number of receptor classes, each of which encodes a certain combination of chemical features. Those representations resemble a multivariate representation of the stimulus space [1]. The insect olfactory system thus provides an efficient basis for bio-inspired computational methods to process and classify multivariate data.

Olfactory receptors typically have broad receptive fields, and the odor spectra of individual receptor classes overlap. From the viewpoint of multivariate data processing, overlapping receptive fields cause correlation between input variables (channel correlation). In previous work, we demonstrated how lateral inhibition in an olfactioninspired network reduced channel correlation $[2,3]$. Decorrelation was achieved by setting the strength of lateral inhibition between two channels according to their correlation, which we pre-computed from the input data.

Here, we propose unsupervised learning of the lateral inhibition structure. The lateral inhibition synapses support inhibitory spike-timing dependent plasticity (iSTDP) $[4,5]$. After exposing the network to a sufficient number of input samples, the inhibitory connectivity self-organizes to reflect the correlation between input channels. We show that this biologically realistic, local learning rule produces an inhibitory connectivity that effectively reduces channel correlation and yields superior network performance in a multivariate scent recognition scenario.

\section{Acknowledgements}

This work was funded by a grant from DFG (SCHM2474/1-2 to MS) and BMBF (01GQ1001D to MS).

'Theoretical Neuroscience, Institute of Biology, Freie Universität Berlin, Berlin, 14195, Germany

Full list of author information is available at the end of the article

\section{Author details}

'Theoretical Neuroscience, Institute of Biology, Freie Universität Berlin, Berlin, 14195, Germany. ${ }^{2}$ Bernstein Center for Computational Neuroscience Berlin, Berlin, 10115, Germany.

Published: 8 July 2013

\section{References}

1. Huerta R, Nowotny T: Fast and Robust Learning by Reinforcement Signals: Explorations in the Insect Brain. Neural Comput 2009, 21:2123-2151.

2. Schmuker M, Schneider G: Processing and classification of chemical data inspired by insect olfaction. PNAS 2007, 104:20285-9.

3. Schmuker M, Yamagata N, Nawrot MP, Menzel R: Parallel representation of stimulus identity and intensity in a dual pathway model inspired by the olfactory system of the honeybee. Front Neuroeng 2011, 4:17.

4. Haas JS, Nowotny T, Abarbanel HDI: Spike-timing-dependent plasticity of inhibitory synapses in the entorhinal cortex. J Neurophysiol 2006, 96:3305-13.

5. Vogels TP, Sprekeler H, Zenke F, Clopath C, Gerstner W: Inhibitory Plasticity Balances Excitation and Inhibition in Sensory Pathways and Memory Networks. Science 2011, 334:1569-73.

doi:10.1186/1471-2202-14-S1-012

Cite this article as: Kasap and Schmuker: Self-organized lateral inhibition improves odor classification in an olfaction-inspired network. BMC Neuroscience 2013 14(Suppl 1):012.

Submit your next manuscript to BioMed Central and take full advantage of:

- Convenient online submission

- Thorough peer review

- No space constraints or color figure charges

- Immediate publication on acceptance

- Inclusion in PubMed, CAS, Scopus and Google Scholar

- Research which is freely available for redistribution
C Biomed Central

๑ 2013 Kasap and Schmuker; licensee BioMed Central Ltd. This is an Open Access article distributed under the terms of the Creative Commons Attribution License (http://creativecommons.org/licenses/by/2.0), which permits unrestricted use, distribution, and reproduction in any medium, provided the original work is properly cited. 